\title{
Water Quality Index as a Tool for Assessment of Status of an Urban Lake of Mumbai
}

\author{
A. Usman ${ }^{1}$, K. Dube ${ }^{1 *}$, S.P. Shukla ${ }^{1}$, P. Salaskar ${ }^{2}$, C. Prakash ${ }^{1}$, \\ P.B. Sawant ${ }^{1}$ and R. Singh ${ }^{1}$ \\ ${ }^{1}$ ICAR-Central Institute of Fisheries Education Mumbai, India \\ ${ }^{2}$ Naushad Ali Sarovar Samvardhini, Powai lake Mumbai, India \\ *Corresponding author
}

\begin{tabular}{|c|}
\hline Keywords \\
\hline $\begin{array}{l}\text { Water quality index, } \\
\text { Aquaculture, } \\
\text { Aquatic bodies, } \\
\text { Powai lake }\end{array}$ \\
\hline Article Info \\
\hline $\begin{array}{l}\text { Accepted: } \\
07 \text { March } 2018 \\
\text { Available Online: } \\
10 \text { April } 2018\end{array}$ \\
\hline
\end{tabular}

\section{Introduction}

The world fish production accounted for 44.1 percent of total production (including for non-food uses) from captures fisheries and aquaculture in 2014, up from 42.1 percent in 2012 and 31.1 percent in 2004. Almost all continents have shown a general trend of an

\section{A B S T R A C T}

This study investigates the effectiveness of water quality index (WQI) for the assessment of aesthetic status of Powai lake by analysing selected parameters. Water quality was monitored monthly for a period of one year (November, 2016 to October, 2017) in five sampling stations (A, B, C, D and E) as a simple pollution indicator for an assessment to initiate appropriate management action. The result reveal that $\mathrm{WQI}_{\mathrm{obj}}$ did not support the results of analysis of variance simply because it is calculated using many variables to assess the overall water quality. The WQI ${ }_{\text {min }}$ yielded high scores (69.07) compared to the $\mathrm{WQI}_{\mathrm{obj}}(63.80)$. However, $W Q \mathrm{I}_{\min }$ was not able to differentiate the reference station and the others to a large extent, though some significant differences for the entire months were observed. This finding was further supported by individual level of concentration between the $\mathrm{WQI}_{\mathrm{obj}}$ and the $\mathrm{WQI}_{\min }$ index scores. The results suggested that water temperature, turbidity, and total phosphate along with carbon dioxide depend on monsoon as a result of the discharges into the lake. A calculation of $\mathrm{WQI}_{\min }$ based on eight parameters confirmed that water quality of the lake can be classified as "fair" however which a condition sometimes depart from natural or desirable levels (average scores between 65 and 79 in annual period) due to varying extent of environmental and anthropogenic factor. Furthermore, $\mathrm{WQI}_{\min }$ can be used as tool for assessment of water quality and employed in monitoring of aquatic body, because it decreases the cost of monitoring of the lake. Overall, the study shows that WQI is an effective parameter to evaluate the water quality of the lake which has a potential for aquaculture especially cage culture. 
molluscs (US\$19 billion), 6.9 million tonnes of crustaceans (US $\$ 36.2$ billion), and 7.3 million tonnes of other aquatic animals including frogs (US\$3.7 billion). Most of the fish produced from aquaculture are destined for human consumption, although by-products may be used for non-food purposes (FAO, 2016).

Use of surface waters for various purposes threatens the integrity of aquatic ecosystems as a result of changing its quality and quantity. Therefore, representative and reliable monitoring and assessment of water quality are critical (Massoud, 2010; Martin and Madelene, 2016). Surface water quality is traditionally assessed by water quality standards and objectives (Rosemond et al., 2009). However, this traditional approach cannot provide sufficient information on the overall quality of water or the spatial and temporal trends (Kannel et al., 2007). Although dynamic mathematical modelling or multivariate statistics are the best approaches to determine these trends (Boyacioglu and Boyacioglu, 2007), they require overmuch effort, financial resource, and expertness and they are not easily applicable or cognizable. Therefore, researchers and/or environmental authorities have strived to derive a simple expression of the general quality of surface waters by a single number, that is, the water quality index (WQI) (Debels et al., 2005).

There are several WQIs using different parameters depending on the water quality objectives all over the world (CCME, 2001; Debels et al., 2005). The WQIs are commonly used in either the classification of surface waters (Boyacioglu, 2010; Lermontov et al., 2011) or the assessment of beneficial use (Said et al., 2004) and water pollution (Akkoyunlu and Akıner, 2012; Bakan et al., 2010; Kannel et al., 2007; Zhang and Zhang, 2007). For example, Pesce and Wunderlin (2000) calculated the objective WQI (WQI ${ }_{\mathrm{obj}}$ ) on 20 parameters and the minimum WQI (WQI $\left.\mathrm{Win}_{\text {m }}\right)$ on three key parameters (dissolved oxygen, electrical conductivity or total dissolved solids, and turbidity) to assess the effect of urban discharge on a receiving river water quality. They suggested that the latter was sufficient as much as the former in the assessment, resulting in a decrease in analytical cost, which is a limiting factor in water quality assessments. Kannel et al., (2007) also showed that the $\mathrm{WQI}_{\min }$ on five parameters (temperature, $\mathrm{pH}$, dissolved oxygen, electrical conductivity and total dissolved solids) could be useful for the periodic routine monitoring program of urban impacts on freshwater bodies.

Environmental impacts of fish farming activities have been well documented and have received increasing attention in the last two or three decades. One of the most significant effects of fish farming is the enrichment of aquatic bodies with phosphorous, ammonia, copper, organic matter and other nutrients and decreases in dissolved oxygen (Hall et al., 1992; Leung et al., 1999; Holby and Hall, 1991; Wu et al., 1994). For fish farming it is important to understand two aspects, the pollution caused by fish farming and, the effects of pollution on fish. The first one refers to changes in water quality due to increasing nutrients and to decreasing dissolved oxygen. Aquatic bodies are only considered as sources of water to supply the countless demands created by human activity and the quality criteria commonly adopted hardly ever take in consideration the maintenance of aquatic life in these bodies, but only the quality of this water for human consumption. This can create problems with some maximum values that are stipulated for parameters of routine management, as the great majority of aquatic organisms may be sensitive to this compound, while for humans the aspect of odour and not toxicity imposes part of the limits in drinking 
water criteria. Many water quality parameters are indispensable to protect aquatic life, for example, with relation to dissolved oxygen, a classic environmental variable whose absence can affect the aquatic biota significantly (Manahan, 2000).

The environmental sustainability of aquaculture, the fastest growing food industry due to the expansion of an annual average growth of $8.3 \%$ for the past three decades (FAO, 2010), is a concern because it can have serious negative impacts on aquatic ecosystems as a result of nutrient and organic matter enrichment (Folke and Kautsky, 1992). The impacts may show clear temporal and spatial variations depending on species, culture method, stocking density, feed type, hydrologic properties, farm capacity and husbandry practices (O'Bryen and Lee, 2003; Tacon and Forster, 2003; Wu, 1995). There are some studies using the WQIs in the assessment of environmental impacts of aquacultural activities. Ferreira et al., (2011) applied the Canadian WQI to assess the effects of shrimp farm activities on two coastal environments using 18 parameters representing physicochemical and biological variations and bacteriological contamination. The investigators did not detect a significant influence in the sites. Simoes et al., (2008) used U.S. National Sanitation Foundation WQI, the minimum operator concept, and the WQI $_{\text {min }}$ in the assessment of the effects of pond aquaculture effluents on stream ecosystem and suggested that the deterioration due to aquacultural activity can be easily inferred with $\mathrm{WQI}_{\min }$ on three parameters: dissolved oxygen, turbidity and total phosphorus. The question of which parameters should be considered and how they are selected in the calculation of WQI for specific assessments of the impacts of aquaculture effluents on lake water quality remains to be answered. Therefore, the objectives of this study were to determine the water quality of
Powai lake using Canadian WQI for aquaculture.

\section{Materials and Methods}

\section{Study area}

Powai Lake is located between latitude $19^{0} 7^{\prime}$ $\mathrm{N}$ and longitude $72^{\circ} 54^{\prime} \mathrm{E}$ with total surface area of $2.10 \mathrm{~km}^{2}$ and 35 meters above the mean sea level. It is a man-made lake built in 1891 and known as 'Anglers Paradise' with catchment area of $6.61 \mathrm{~km}^{2}$, maximum depth of $12 \mathrm{~m}$ and surface elevation of $58.5 \mathrm{~m}$. It is meant exclusively for angling and sports and is located about $27 \mathrm{Km}$ away in the north- east of Mumbai city. This lake came into existence in the year 1891, when Mumbai Municipality got constructed a monsonary dam of 10 meter height between two hillocks across Powai basin to conserve the rain water for drinking purpose, which is commonly known as Powai lake, since it impounded in Powai area (Kohil et al., 1998). However, the water in the lake was found in potable because of indiscriminate use of the lake for various purposes by the local people and also due to the addition of domestic sewage. This lake was open for the general utilization of the natives and it is leased out Maharashtra State Angling Association, Mumbai for angling in addition to conservation. The conservation of Powai Lake is in the interest of man as it's ecological, aquacultural and tourist value. One of the most important steps in the conservation of the lake is to restore the water quality by controlling the pollution through different remedial measures (Fig. 1).

\section{Sampling stations}

Five sampling stations were chosen based on preliminary surveys of the lake and factors such as average depth, volume of water, accessibility, security and various activities taking place in and around the lake. GPS was 
used to locate the coordinates of the station A (19.1259 and 72.8979), station B (19.1330 and 72.9030), station C (19.1263 and 72.9032), station D (19.1285 and 72.9108) and station E (19.1213 and 72.9047) respectively (Fig. 1).

\section{Water quality analysis}

The samples were taken on monthly basis between November 2016 and October 2017. Atmospheric temperature (A/T), surface water temperature (W/T), dissolved oxygen (DO), $\mathrm{pH}$, and electrical conductivity (EC) were measured in situ by FB 61317, LT-II, and PC 510 model field instruments (fitted with thermometer) respectively. Biochemical oxygen demand (BOD) was determined by modified Winkler's method. Transparency (T) and turbidity (Turb) were measured using secchi disc and turbidity meter. Total solid (TS), total suspended solids (TSS) and total dissolved solids (TDS) were determined by filtration and then dried at 103-105 ${ }^{\circ} \mathrm{C}$. Ammonia nitrogen $\left(\mathrm{NH}_{4}{ }^{+}-\mathrm{N}\right)$, nitrite nitrogen $\left(\mathrm{NO}_{2}{ }^{-} \mathrm{N}\right)$, nitrate nitrogen $\left(\mathrm{NO}_{3}^{-}{ }^{-} \mathrm{N}\right)$, and phosphorus (P) were determined by UV/VIS spectrophotometer 2080 system. Alkalinity, hardness, chloride, chemical oxygen demand (COD) and free dissolved carbon dioxide $\left(\mathrm{CO}_{2}\right)$ were analyzed by titration method. All water quality analyses were performed according to Standard Methods for the Examination of Water and Wastewater (APHA, AWWA, WEF, 1998) and data were statistically analysed using one-way analysis of variance (ANOVA-IBM SPSS version 22), and the significant differences between the means were determined by Duncan's Multiple Range Test (DMRT). The significance level was made at $\mathrm{P}<0.05$. Data are as mean \pm standard error of the mean.

\section{Water quality index}

Water quality index (WQI) created by Canadian water quality guideline for the protection of aquatic life (CCME, 2001) was used for assessment of water quality in the lake. The WQI is a mathematical instrument used to transform large quantities of water quality data into a single number which summarize different quality parameters. The WQI is an index of water quality for a particular use. Mathematically, the index is an arithmetic weighting of normalized water quality measurements.

WQI is calculated using the following equation:

$F_{1}$ (Scope) represents the percentage of variables that do not meet their objectives at least once during the time period under consideration ("failed variables"), relative to the total number of variables measured:

$$
\text { F1 }=\frac{\text { Number of failed variable }}{\text { Total number of variable }} \times 100 \text { (1) }
$$

$F_{2}$ (Frequency) represents the percentage of individual tests that do not meet objectives ("failed tests"):

F2 $=\frac{\text { Number of failed tests }}{\text { Total number of tests }} \times 100$ (2)

$F_{3}$ (Amplitude) represents the amount by which failed test values do not meet their objectives. $F_{3}$ is calculated in three steps.

The number of times by which an individual concentration is greater than (or less than, when the objective is a minimum) the objective is termed an "excursion" and is expressed as follows. When the test value must not exceed the objective:

excursion $\mathrm{i}=\frac{\text { Failed Test Value }}{\text { objective } \mathrm{i}}-1$ (3a)

For the cases in which the test value must not fall below objectives: 
excursion $\mathrm{i}=\frac{\text { Objective } i}{\text { Failed Test Value } i}-1$

The collective amount by which individual tests are out of compliance is calculated by summing the excursions of individual tests from their objectives and dividing by the total number of tests (both those meeting objectives and those not meeting objectives). This variable, referred to as the normalized sum of excursions, or $n s e$, is calculated as:

$n s e=\sum \frac{\frac{\sum}{i-1} \text { excursion } i}{\text { Number of tests }}$

$F_{3}$ is then calculated by an asymptotic function that scales the normalized sum of the excursions from objectives (nse) to yield a range between 0 and 100 .

$\mathrm{F} 3=\frac{\text { nse }}{0.01 \text { nse }+0.01}(5)$

Once the factors have been obtained, the index itself was calculated by summing the three factors as if they were vectors. The sum of the squares of each factor is therefore equal to the square of the index. This approach treats the index as a three-dimensional space defined by each factor along one axis. With this model, the index changes in direct proportion to changes in all three factors.

The CCME Water Quality Index (CCME WQI)

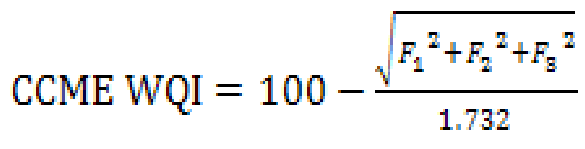

The divisor 1.732 normalises the resultant values to a range between 0 and 100, where 0 represents the 'worst' water quality and 100 represents the 'best' water quality that has been most important for aquatic life preservation.

\section{Results and Discussion}

All the 20 parameters used this study were present except free dissolved carbon dioxide $\left(\mathrm{CO}_{2}\right)$ that is available only in the month of Feb, Jun and Oct. pH, Biochemical Oxygen Demand (BOD), alkalinity, ammonia $\left(\mathrm{NH}_{4}{ }^{-}-\right.$ $\mathrm{N})$, nitrate $\left(\mathrm{NO}_{3}-\mathrm{N}\right)$, total solid (TS), total dissolved solid (TDS) and total suspended solid (TSS) were within the recommended level for aquatic life (Table 1). High level in ambient temperature $(\mathrm{A} / \mathrm{T})$, surface water temperature (W/T), transparency (Trans), turbidity, DO, chloride, total phosphorus (TP), nitrite $\left(\mathrm{NO}_{2}-\mathrm{N}\right)$, Chemical Oxygen Demand (COD), conductivity and $\mathrm{CO}_{2}$ was recorded while low in ambient temperature, water temperature, transparency, turbidity, DO, hardness, COD and conductivity across the months. Lowest ambient temperature was recorded in the month of December and highest in May, there is no significance difference $(p<0.05)$ in November and January; March and June; February, April, July, August and October while significant difference ( $>$ >0.05) in December, September and May. Lowest water temperature was recorded in December while highest value in March, there is significance difference $(p>0.05)$ between all the study months. Highest transparency was recorded in September and lowest in May, November, September, and October are significantly difference $(\mathrm{P}>0.05)$ also with the rest of the months.

Highest turbidity was recorded in May while lowest in September, there is significance difference $(p>0.05)$ within the months except in November, January and August; December and July; and March and May. TS, TDS and TSS were low in February, November and January while there was high in August and March respectively. No significance difference $(\mathrm{p}<0.05)$ between May and August; November and March; and April was observed as compared with rest of the months for TS, 
TDS and TSS. pH was highest in September and lowest in November, significance difference $(p>0.05)$ observed in the entire months except in December, January and June; and April and May.

Alkalinity was lowest in August and highest in October, there is no significance difference $(p<0.05)$ in December and January; February and August; March and April; May and July while rest of the months are significantly different $(p>0.05)$. Highest value of hardness was recorded in June and lowest in December, month of December and January; March and April are not significantly different $(p<0.05)$, while there is significant difference in rest of the months. Chloride and total phosphate are low in December while high in May and October respectively (Table 2), No significant difference $(p<0.05)$ in February and April for chloride and significance difference $(p>0.05)$ in May and October. In term of $\mathrm{NH}_{4}+-\mathrm{N}$, lowest value was recorded in January and highest in September, there is significance difference $(p>0.05)$ in December, January and July with rest of the months. $\mathrm{NO}_{2}-\mathrm{-N}$ was low in October and high in June, there is a significance difference $(p>0.05)$ in June, August and October; and no difference in rest of the months. $\mathrm{NO}_{3}-\mathrm{-N}$ was highest in June and lowest in December, significance difference $(p>0.05)$ was observed in December, February and May while it was insignificant difference $(p<0.05)$ in rest of the months. In term of phosphate, highest value was recorded in October and lowest in March, there is no significance difference $(\mathrm{P}<0.05)$ across the study months except in February and October. Lowest DO was in May and highest in September, there is no significance difference $(\mathrm{p}<0.05)$ in the month of December and February; March and October; and April and June. For $\mathrm{CO}_{2}$, high concentration was present in June and low in February, there is no significance difference $(\mathrm{P}<0.05)$ in February, June, October and other months.
Highest BOD was observed in September and lowest in January, and no significance difference $(\mathrm{p}<0.05)$ in February, May, June, July and October while rest of the months are significantly different ( $p>0.05$ ).

COD was high in April and low in January, and a significance difference $(\mathrm{P}>0.05)$ was observed in May, June, July, August, September and October compare to other months. Conductivity was low in October and high in July, with insignificance difference $(\mathrm{P}<0.05)$ in months of January and February; and significantly different with rest of the months.

Evaluation of overall water quality is not an easy task, particularly when different criteria for different uses are applied. Moreover, the classification of water quality follows various definitions with respect to the contents of different water quality parameters. Dozens of variables have been developed and are available to be used in management governmental or environmental programs, but because of the high price for water analysis to attend these programs generally makes it difficult to use them. In this study, application of the water quality index approach to Powai lake has the objective of providing a simple and valid method for expressing the results of several parameters in order to more rapidly and conveniently assess the water quality for aquaculture. Combining different parameters into one single number leads to an easy interpretation of the index, thus providing an important tool for management purposes. The CCME WQI rank, defines Excellent water quality as (CCME WQI value 95-100), Good (CCME WQI value 80-94), Fair (CCME WQI value 65-79), Marginal (CCME WQI value 45-64), and Poor (CCME WQI value 0-44) respectively. The assigning of CCME WQI values to these categories is termed "categorization" and represents a critical but somewhat subjective process. 
Table.1 Monthly mean variation in Physico-chemical Parameters of Powai lake (Nov, 2016 to Oct, 2017)

\begin{tabular}{|c|c|c|c|c|c|c|c|c|c|c|c|}
\hline Months & A/temp $\left({ }^{0} \mathrm{C}\right)$ & W/temp $\left({ }^{0} \mathrm{C}\right)$ & $\begin{array}{l}\text { Transparency } \\
\text { (cm) }\end{array}$ & $\begin{array}{l}\text { Turbidity } \\
\text { (NTU) }\end{array}$ & Depth (m) & TS $\left(\mathrm{mg}^{-1}\right)$ & $\begin{array}{l}\text { TDS (mg- } \\
\text { 1) }\end{array}$ & TSS $\left(\mathrm{mg}^{-1}\right)$ & pH & $\begin{array}{l}\text { Alkalinity } \\
\left(\mathrm{mg}^{-1}\right)\end{array}$ & $\begin{array}{l}\text { Hardness } \\
\left(\mathrm{mg}^{-1}\right)\end{array}$ \\
\hline Nov & $26.33 \pm 0.25^{b}$ & $25.94 \pm 0.09^{c}$ & $38.26 \pm 1.41^{\mathrm{g}}$ & $47.46 \pm 2.12^{d}$ & $4.26 \pm 0.28^{a}$ & $200 \pm 0.01^{\mathrm{a}}$ & $20 \pm 0.00^{\mathrm{a}}$ & $200 \pm 0.03^{c}$ & $7.12 \pm 0.01^{\mathrm{a}}$ & $133.46 \pm 2.56^{\mathrm{e}}$ & $138.80 \pm 1.80^{\mathrm{fg}}$ \\
\hline Dec & $24.51 \pm 0.19^{\mathrm{a}}$ & $23.75 \pm 0.12^{\mathrm{a}}$ & $28.60 \pm 0.86^{\mathrm{d}}$ & $34.33 \pm 1.37^{c}$ & $4.27 \pm 0.22^{\mathrm{a}}$ & $210 \pm 0.00^{\mathrm{a}}$ & $170 \pm 0.01^{\mathrm{c}}$ & $60 \pm 0.01^{\mathrm{a}}$ & $7.18 \pm 0.01^{b}$ & $127.73 \pm 0.80^{\mathrm{d}}$ & $20.93 \pm 1.30^{\mathrm{a}}$ \\
\hline Jan & $26.36 \pm 0.32^{b}$ & $24.31 \pm 0.03^{b}$ & $34.90 \pm 0.80^{f}$ & $47.26 \pm 1.73^{\mathrm{d}}$ & $4.16 \pm 0.30^{\mathrm{a}}$ & $190 \pm 0.00^{\mathrm{a}}$ & $140 \pm 0.01^{\mathrm{c}}$ & $50 \pm 0.00^{\mathrm{a}}$ & $7.18 \pm 0.02^{b}$ & $128.13 \pm 0.94^{\mathrm{d}}$ & $22.66 \pm 1.50^{a}$ \\
\hline Feb & $29.31 \pm 0.38^{\mathrm{d}}$ & $29.12 \pm 0.33^{d}$ & $24.46 \pm 0.45^{\mathrm{c}}$ & $57.33 \pm 1.13^{f}$ & $6.90 \pm 2.93^{b}$ & $180 \pm 0.00^{\mathrm{a}}$ & $140 \pm 0.01^{\mathrm{c}}$ & $60 \pm 0.01^{\mathrm{a}}$ & $7.32 \pm 0.01^{\mathrm{c}}$ & $109.06 \pm 2.63^{b}$ & $113.20 \pm 3.93^{c}$ \\
\hline Mar & $28.19 \pm 0.42^{c}$ & $31.34 \pm 0.12^{\mathrm{h}}$ & $17.80 \pm 0.49^{a}$ & $85.66 \pm 1.68^{h}$ & $3.36 \pm 0.33^{\mathrm{a}}$ & $240 \pm 0.01^{\mathrm{a}}$ & $220 \pm 0.01^{d}$ & $80 \pm 0.02^{\mathrm{ab}}$ & $7.38 \pm 0.00^{\mathrm{e}}$ & $107.20 \pm 1.54^{\mathrm{ab}}$ & $98.13 \pm 1.78^{b}$ \\
\hline$\overline{A p r}$ & $29.76 \pm 0.22^{\mathrm{d}}$ & $31.24 \pm 0.03^{\mathrm{gh}}$ & $20.10 \pm 0.31^{b}$ & $79.33 \pm 1.75^{\mathrm{g}}$ & $3.28 \pm 0.32^{\mathrm{a}}$ & $210 \pm 0.00^{\mathrm{a}}$ & $170 \pm 0.01^{\mathrm{c}}$ & $60 \pm 0.01^{\mathrm{a}}$ & $7.44 \pm 0.02^{\mathrm{fg}}$ & $106.80 \pm 0.69^{\mathrm{ab}}$ & $99.20 \pm 1.24^{b}$ \\
\hline May & $32.39 \pm 0.16^{\mathrm{f}}$ & $32.92 \pm 0.04^{\mathrm{i}}$ & $16.96 \pm 0.29^{a}$ & $88.33 \pm 1.59^{h}$ & $2.83 \pm 0.35^{a}$ & $380 \pm 0.06^{b}$ & $170 \pm 0.00^{c}$ & $210 \pm 0.06^{c}$ & $7.47 \pm 0.01^{\mathrm{fg}}$ & $116.26 \pm 2.22^{c}$ & $122.66 \pm 3.54^{d}$ \\
\hline Jun & $27.66 \pm 0.15^{c}$ & $29.42 \pm 0.03^{\mathrm{de}}$ & $28.33 \pm 0.33^{\mathrm{d}}$ & $52.53 \pm 0.55^{\mathrm{e}}$ & $4.19 \pm 0.38^{\mathrm{a}}$ & $250 \pm 0.01^{\mathrm{a}}$ & $90 \pm 0.01^{b}$ & $150 \pm 0.01^{b c}$ & $7.18 \pm 0.01^{b}$ & $102.66 \pm 1.46^{\mathrm{a}}$ & $152.26 \pm 5.44^{\mathrm{h}}$ \\
\hline Jul & $29.92 \pm 0.25^{\mathrm{d}}$ & $29.66 \pm 0.04^{\mathrm{ef}}$ & $31.18 \pm 0.35^{\mathrm{e}}$ & $33.93 \pm 1.49^{c}$ & $4.20 \pm 0.37^{\mathrm{a}}$ & $190 \pm 0.00^{\mathrm{a}}$ & $90 \pm 0.00^{b}$ & $90 \pm 0.01^{\mathrm{ab}}$ & $7.38 \pm 0.01^{\mathrm{de}}$ & $120.13 \pm 2.06^{c}$ & $135.73 \pm 2.61^{f}$ \\
\hline Aug & $29.82 \pm 0.22^{\mathrm{d}}$ & $29.39 \pm 0.03^{\mathrm{de}}$ & $26.10 \pm 1.01^{\mathrm{c}}$ & $45.33 \pm 1.88^{\mathrm{d}}$ & $4.06 \pm 0.36^{\mathrm{a}}$ & $410 \pm 0.01^{b}$ & $90 \pm 0.01^{b}$ & $320 \pm 0.02^{\mathrm{d}}$ & $7.40 \pm 0.00^{\mathrm{ef}}$ & $110.40 \pm 0.94^{\mathrm{b}}$ & $145.06 \pm 2.40^{\text {gh }}$ \\
\hline Sep & $31.16 \pm 0.18^{\mathrm{e}}$ & $30.94 \pm 0.09^{g}$ & $42.36 \pm 0.81^{h}$ & $24.93 \pm 0.72^{a}$ & $3.95 \pm 0.37^{\mathrm{a}}$ & $200 \pm 0.03^{\mathrm{a}}$ & $90 \pm 0.12^{b}$ & $130 \pm 0.02^{\mathrm{ab}}$ & $7.50 \pm 0.01^{\mathrm{g}}$ & $149.06 \pm 2.08^{f}$ & $126.40 \pm 1.99^{\mathrm{de}}$ \\
\hline Oct & $29.66 \pm 0.27^{\mathrm{d}}$ & $29.82 \pm 0.04^{f}$ & $34.40 \pm 0.44^{\mathrm{f}}$ & $29.73 \pm 0.81^{b}$ & $3.69 \pm 0.34^{\mathrm{a}}$ & $180 \pm 0.00^{\mathrm{a}}$ & $100 \pm 0.00^{b}$ & $80 \pm 0.01^{\mathrm{ab}}$ & $7.34 \pm 0.01^{\mathrm{cd}}$ & $215.73 \pm 1.40^{\mathrm{g}}$ & $132.53 \pm 1.98^{\mathrm{ef}}$ \\
\hline Obj. & 25-32 & 24-27 & $20-35$ & $<30$ & & $<500$ & $<500$ & $30-200$ & $6.7-9.5$ & $50-300$ & $30-180$ \\
\hline
\end{tabular}

Means $( \pm \mathrm{SE})$ in the same column having different superscripts are significantly $(\mathrm{P}<0.05)$ different

Table.2 Monthly mean variation in Water Quality Parameters of Powai lake (Nov, 2016 to Oct, 2017)

\begin{tabular}{|c|c|c|c|c|c|c|c|c|c|c|}
\hline Months & Chloride $\left(\mathrm{mg}^{-1}\right)$ & $\mathrm{NH}_{4}^{+}-\mathrm{N}\left(\mathrm{mg}^{-1}\right)$ & $\mathrm{NO}_{2}-\mathbf{N}\left(\mathrm{mg}^{-1}\right)$ & $\mathrm{NO}_{3}-\mathrm{N}\left(\mathrm{mg}^{-1}\right)$ & Phosphate $\left(\mathrm{mg}^{-1}\right)$ & DO $\left(\mathrm{mg}^{-1}\right)$ & $\mathrm{CO}_{2}\left(\mathrm{mg}^{-1}\right)$ & BOD $\left(\mathrm{mg}^{-1}\right)$ & $\mathrm{COD}\left(\mathrm{mg}^{-1}\right)$ & Cond. ( $\mu S / \mathrm{cm})$ \\
\hline Nov & $64.00 \pm 2.46^{\mathrm{g}}$ & $0.41 \pm 0.02^{\mathrm{bc}}$ & $0.14 \pm 0.03^{b}$ & $2.73 \pm 0.15^{\mathrm{t}}$ & $1.30 \pm 0.11^{\mathrm{a}}$ & $5.49 \pm 0.17^{b}$ & $0.00 \pm 0.00^{\mathrm{a}}$ & $3.70 \pm 0.36^{\mathrm{b}}$ & $44.13 \pm 2.05^{\mathrm{bc}}$ & $244.33 \pm 0.58^{\mathrm{d}}$ \\
\hline Dec & $32.00 \pm 0.43^{\mathrm{a}}$ & $0.28 \pm 0.01^{\mathbf{b}}$ & $0.06 \pm 0.00^{\mathrm{ab}}$ & $0.20 \pm 0.02^{\mathrm{a}}$ & $0.17 \pm 0.03^{\mathrm{a}}$ & $6.29 \pm 0.21^{\mathrm{cd}}$ & $0.00 \pm 0.00^{\mathrm{a}}$ & $4.38 \pm 0.44^{\mathrm{bc}}$ & $14.26 \pm 2.63^{\mathrm{a}}$ & $253.00 \pm 0.47^{\mathrm{e}}$ \\
\hline Jan & $34.00 \pm 0.55^{\mathrm{ab}}$ & $0.06 \pm 0.00^{\mathrm{a}}$ & $0.05 \pm 0.01^{\mathrm{ab}}$ & $0.63 \pm 0.03^{\mathrm{bc}}$ & $0.49 \pm 0.00^{b}$ & $7.09 \pm 0.21^{\mathrm{e}}$ & $0.00 \pm 0.00^{\mathrm{a}}$ & $2.29 \pm 0.39^{\mathrm{a}}$ & $12.80 \pm 0.47^{\mathrm{a}}$ & $292.26 \pm 0.67^{\mathrm{g}}$ \\
\hline Feb & $45.20 \pm 0.54^{f}$ & $0.37 \pm 0.07^{\mathrm{bc}}$ & $0.03 \pm 0.00^{\mathrm{ab}}$ & $0.76 \pm 0.01^{c}$ & $2.46 \pm 0.11^{\mathrm{e}}$ & $6.32 \pm 0.34^{\mathrm{cd}}$ & $6.80 \pm 1.01^{\mathrm{b}}$ & $6.25 \pm 0.52^{\mathrm{d}}$ & $42.66 \pm 3.74^{\mathrm{bc}}$ & $288.86 \pm 1.19^{g}$ \\
\hline Mar & $44.00 \pm 0.64^{\mathrm{ef}}$ & $0.40 \pm 0.06^{\mathrm{bc}}$ & $0.12 \pm 0.03^{\mathrm{ab}}$ & $1.85 \pm 0.23^{\mathrm{e}}$ & $0.17 \pm 0.00^{\mathrm{a}}$ & $6.72 \pm 0.29^{\mathrm{de}}$ & $0.00 \pm 0.00^{\mathrm{a}}$ & $7.63 \pm 031^{\mathrm{e}}$ & $121.06 \pm 0.67^{\mathrm{h}}$ & $283.13 \pm 1.23^{\mathrm{f}}$ \\
\hline Apr & $46.13 \pm 0.56^{\mathrm{t}}$ & $0.40 \pm 0.06^{\mathrm{bc}}$ & $0.11 \pm 0.02^{\mathrm{ab}}$ & $1.91 \pm 0.22^{\mathrm{e}}$ & $0.18 \pm 0.00^{\mathrm{a}}$ & $5.70 \pm 0.18^{b c}$ & $0.00 \pm 0.00^{\mathrm{a}}$ & $5.33 \pm 0.53^{\mathrm{cd}}$ & $123.46 \pm 0.49^{\mathrm{h}}$ & $321.00 \pm 1.55^{\mathrm{h}}$ \\
\hline May & $67.73 \pm 1.89^{\mathrm{h}}$ & $0.43 \pm 0.03^{\mathrm{bc}}$ & $0.02 \pm 0.00^{\mathrm{a}}$ & $1.39 \pm 0.07^{\mathrm{d}}$ & $2.09 \pm 0.07^{\mathrm{d}}$ & $3.46 \pm 0.18^{\mathrm{a}}$ & $0.00 \pm 0.00^{\mathrm{a}}$ & $5.62 \pm 0.20^{\mathrm{d}}$ & $112.53 \pm 2.77^{g}$ & $480.80 \pm 2.83^{j}$ \\
\hline Jun & $40.93 \pm 0.64^{\mathrm{de}}$ & $0.36 \pm 0.02^{b c}$ & $1.29 \pm 0.10^{\mathrm{d}}$ & $3.00 \pm 0.00^{f}$ & $0.45 \pm 0.01^{\mathrm{b}}$ & $5.86 \pm 0.22^{b c}$ & $13.20 \pm 4.52^{\mathrm{d}}$ & $6.41 \pm 0.23^{\mathrm{d}}$ & $83.06 \pm 2.42^{\mathrm{e}}$ & $370.46 \pm 2.01^{\mathrm{i}}$ \\
\hline Jul & $38.53 \pm 0.60^{\mathrm{cd}}$ & $0.66 \pm 0.09^{d}$ & $0.03 \pm 0.00^{\mathrm{ab}}$ & $0.35 \pm 0.02^{\mathrm{ab}}$ & $0.59 \pm 0.02^{b}$ & $10.80 \pm 0.31^{\mathrm{g}}$ & $0.00 \pm 0.00^{\mathrm{a}}$ & $6.36 \pm 0.37^{\mathrm{d}}$ & $39.60 \pm 2.90^{\mathrm{b}}$ & $602.73 \pm 4.33^{\mathrm{k}}$ \\
\hline Aug & $38.26 \pm 0.61^{\mathrm{cd}}$ & $0.33 \pm 0.06^{\mathrm{bc}}$ & $0.28 \pm 0.03^{c}$ & $2.73 \pm 0.15^{\mathrm{f}}$ & $0.47 \pm 0.03^{b}$ & $9.25 \pm 0.25^{\mathrm{f}}$ & $0.00 \pm 0.00^{\mathrm{a}}$ & $8.42 \pm 0.44^{\mathrm{ef}}$ & $59.33 \pm 4.91^{\mathrm{d}}$ & $177.26 \pm 2.11^{\mathrm{c}}$ \\
\hline Sep & $36.80 \pm 1.87^{b c}$ & $0.48 \pm 0.08^{c}$ & $0.04 \pm 0.01^{\mathrm{ab}}$ & $0.56 \pm 0.10^{\mathrm{bc}}$ & $0.53 \pm 0.01^{b}$ & $13.81 \pm 029^{\mathrm{h}}$ & $0.00 \pm 0.00^{\mathrm{a}}$ & $9.02 \pm 0.44^{\mathrm{f}}$ & $97.73 \pm 4.13^{f}$ & $157.20 \pm 1.26^{\mathrm{b}}$ \\
\hline Oct & $32.53 \pm 0.56^{\mathrm{a}}$ & $0.47 \pm 0.03^{c}$ & $0.01 \pm 0.00^{\mathrm{a}}$ & $0.67 \pm 0.03^{b c}$ & $5.00 \pm 0.00^{\mathrm{f}}$ & $6.72 \pm 0.24^{\mathrm{de}}$ & $9.73 \pm 1.27^{\mathrm{c}}$ & $5.92 \pm 0.53^{d}$ & $48.66 \pm 2.58^{c}$ & $142.13 \pm 2.22^{\mathrm{a}}$ \\
\hline Obj. & $31-50$ & $0-1$ & $0-0.5$ & 0.1-3 & $0.05-0.4$ & $5-10$ & $<3$ & $<10$ & $<50$ & $150-500$ \\
\hline
\end{tabular}

Means $( \pm \mathrm{SE})$ in the same column having different superscripts are significantly $(\mathrm{P}<0.05)$ different 
Fig.1 Map of Powai lake showing the sampling stations

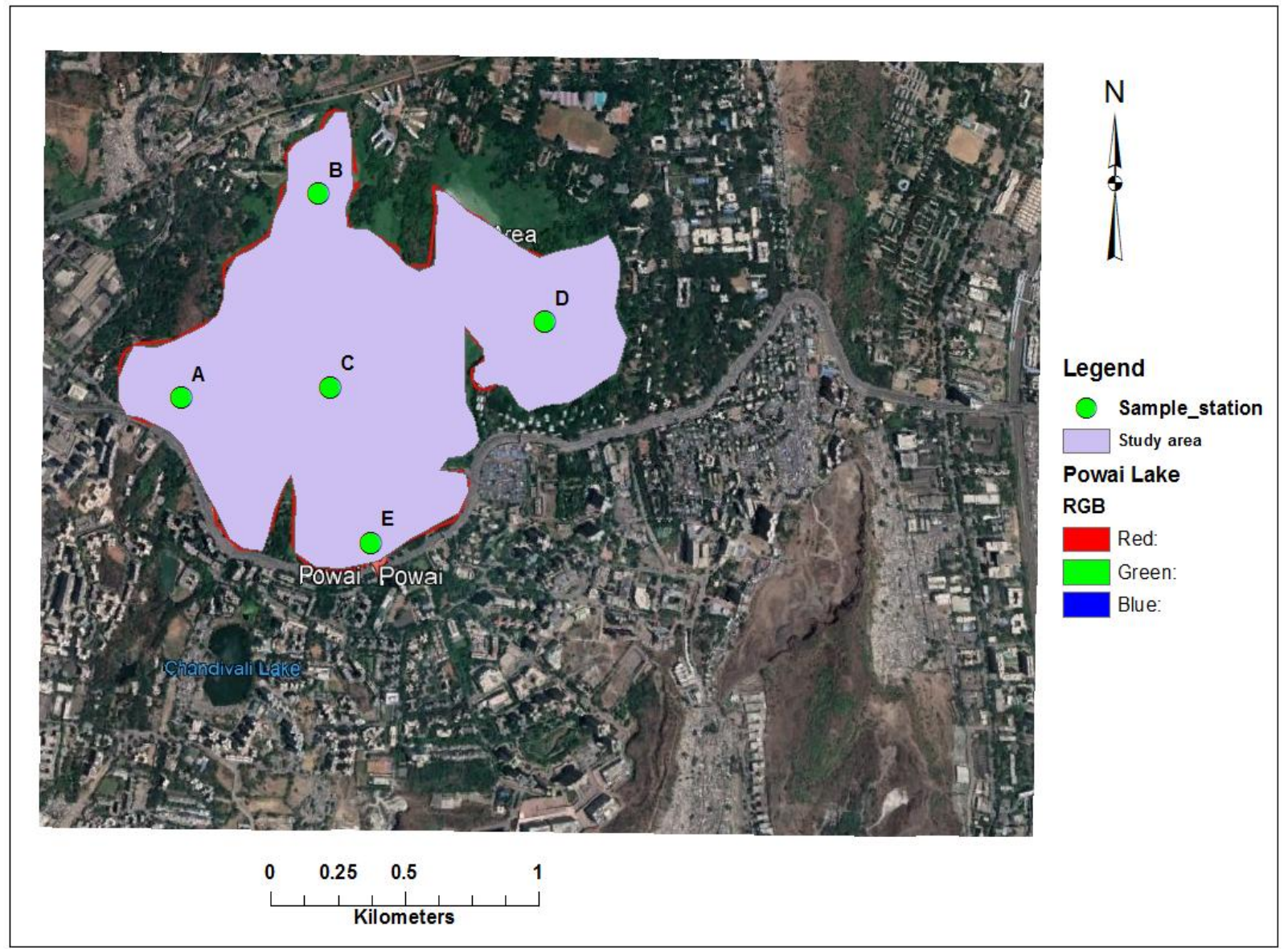

Fig.2 Scores in sampling months of nitrite, nitrate and ammonia

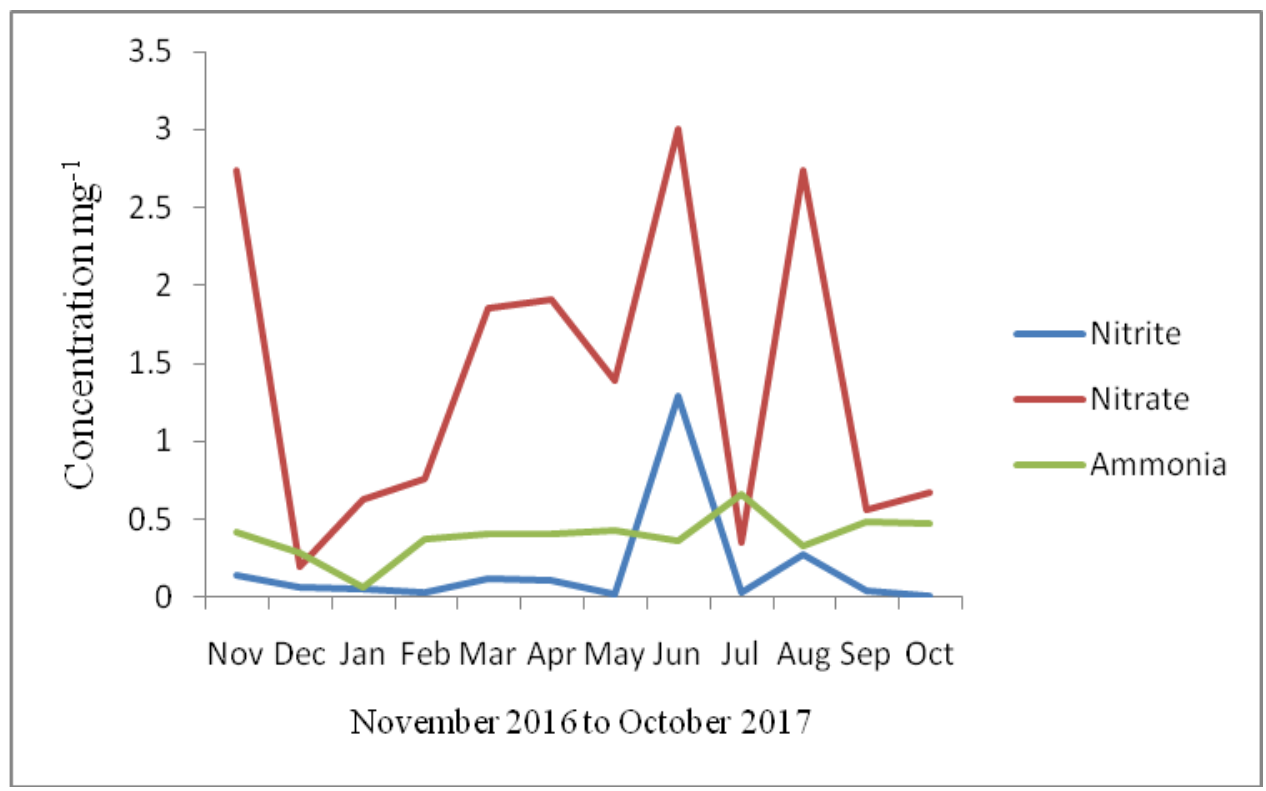


Fig.3 Variation in TS, TDS and TSS of the study

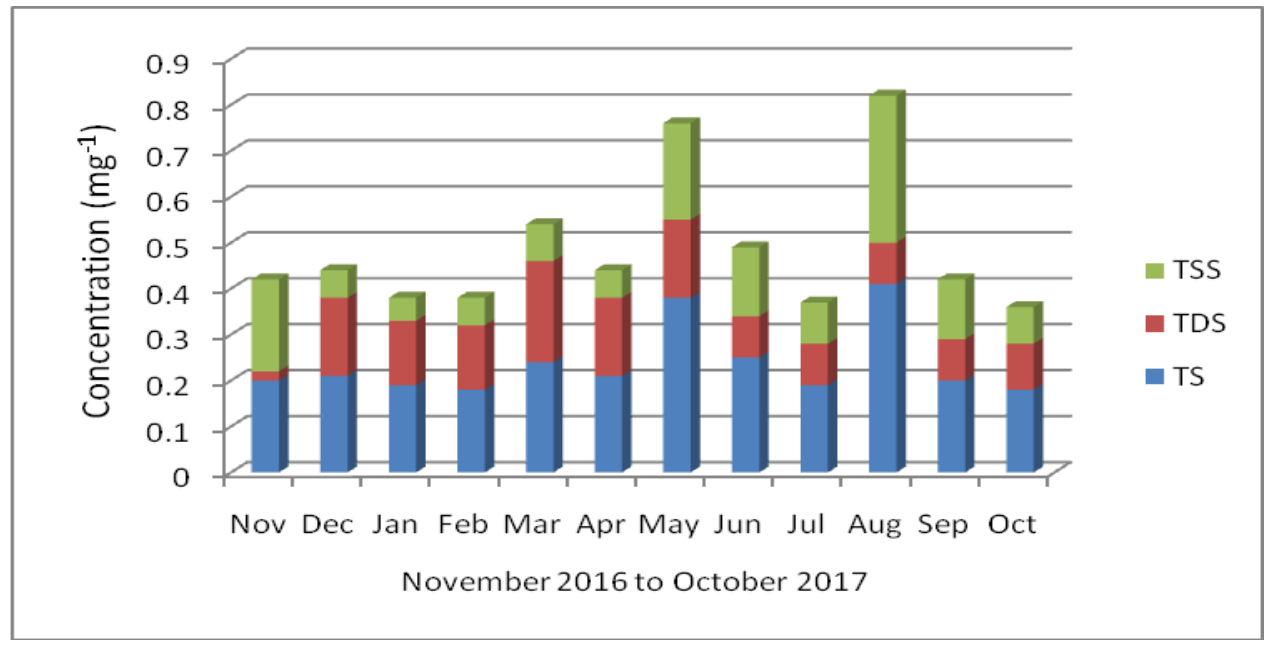

Fig.4 Relationship of DO and BOD (as DO increase BOD also increases during pre-monsoon and post-monsoon)

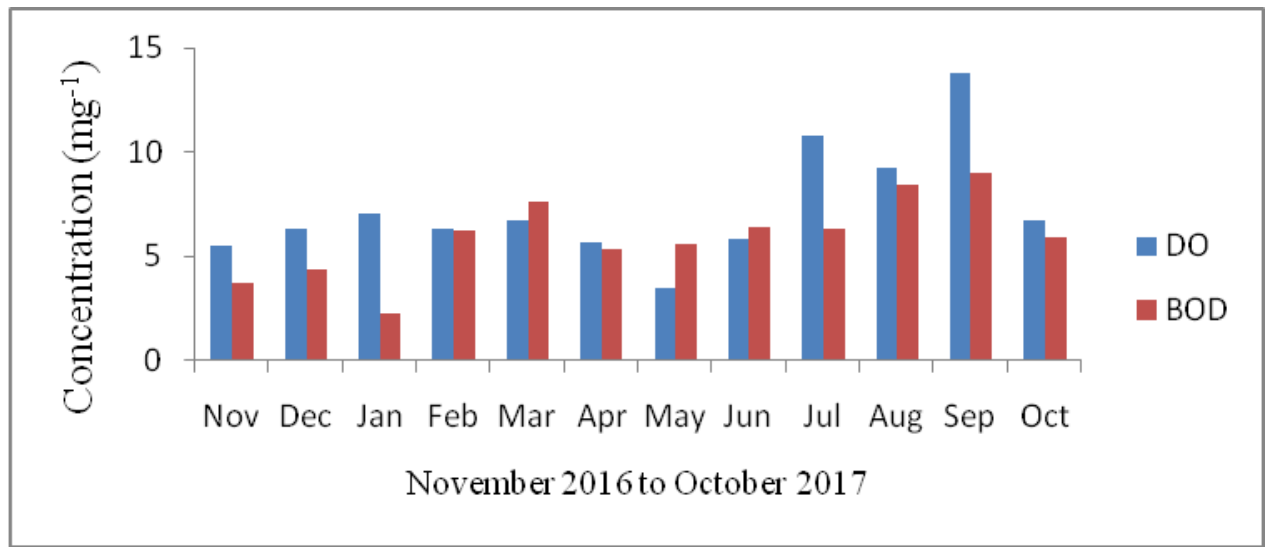

Fig.5 Relationship of ambient temperature and water temperature

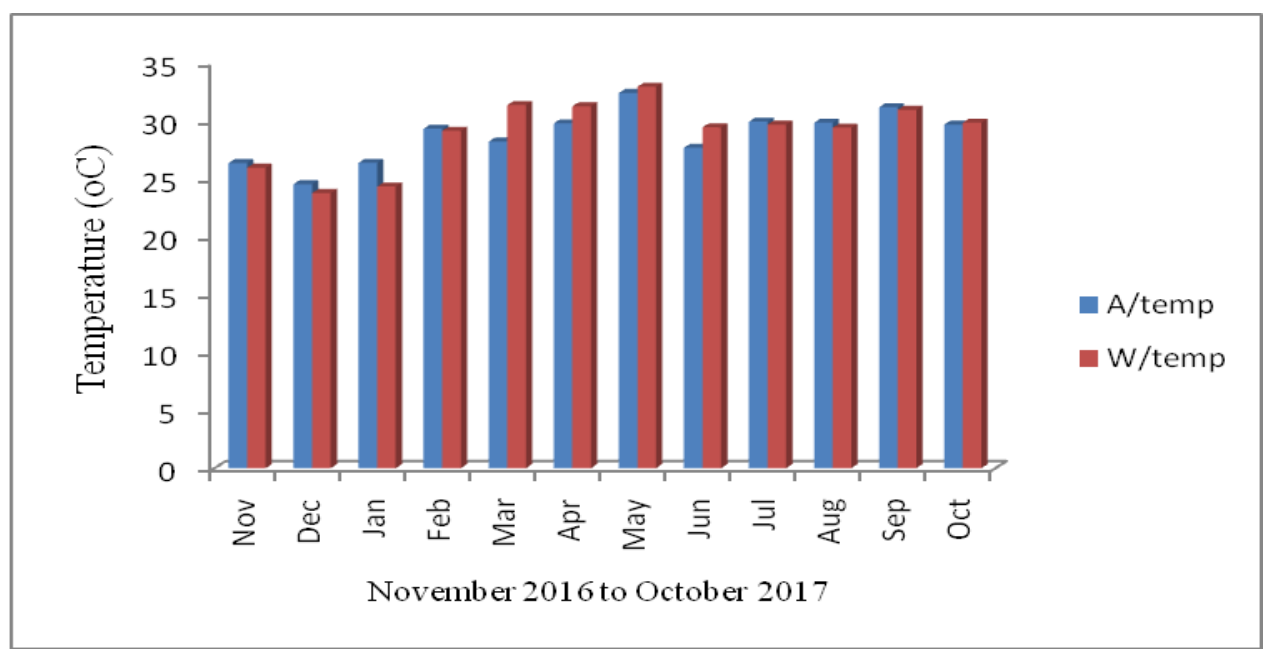


The categorization is based on the best available information, expert judgment, and the general public's expectations of water quality.

$\mathrm{WQI}_{\mathrm{obj}}$ showed no significance difference between the sampling stations in general when the differences between station A, B, C, $D$ and $E$ were relatively in the same amplitude. $\mathrm{WQI}_{\mathrm{obj}}$ did not support the results of analysis of variance simply because it is calculated using many variables to assess the overall water quality. This speculation is further supported by the findings of Ferreira $e t$ al., (2011), who used same method in estimating water quality using the WQI of the Canadian Council of Ministers of the Environment by including a large set of parameters and did not detect a significance difference between qualities of affected and unaffected sites from shrimp farms. Therefore, there is a clear need for the parameter selection and data reduction to clarify the aquacultural impacts, which is the main purpose for the present study.

Data selection and reduction by omitting the unnecessary variables such as depth can be an option to make $\mathrm{WQI}_{\mathrm{obj}}$ simpler. In this study, eight parameters were used to calculate $\mathrm{WQI}_{\min }$ considering that these variables have impacts on the water quality (Bergheim and Brinker, 2003; Sindilariu et al., 2009a; Koc ser et al., 2013). The $\mathrm{WQI}_{\min }$ in this way yielded high score (69.07) compared to the $\mathrm{WQI}_{\mathrm{obj}}$ (63.80). However, $\mathrm{WQI}_{\min }$ was not able to separate the reference station and the others to a large extent, though some significant differences for the entire months were observed. One explanation of this can be that since both urban and domestic waste are also sources of the parameters included in the calculation of $\mathrm{WOI}_{\min }$ in rivers, streams and lakes (Carpenter et al., 1998; Mander et al., 2000; Neal and Jarvie, 2005; Jarvie et al., 2008 and Moss, 2008) it may not have clearly separated the affected sampling stations in the present study.

Instead of an arbitrary selection of the parameters in the calculation of $\mathrm{WQI}_{\min }$, it is assumed that statistical results would be more appropriate way to select the representatives of aquacultural impacts in the study area. The results suggested that $\mathrm{W} / \mathrm{T}$, turbidity, and TP along with COD were more associated with the monsoon as a result of the discharges into the lake. A calculation of $\mathrm{WQI}_{\min }$ based on these eight parameters classified the water quality as "fair" water quality is usually protected but occasionally threatened or impaired; conditions sometimes depart from natural or desirable levels (average scores between 65 and 79 in annual period) whereas, other impacted points as "Marginal" (the index scores between 45 and 64). These results seemed to be more accurate in terms of characterizations for aquaculture potentials.

There were strong and significant relation between $\mathrm{NH}_{4}+-\mathrm{N}, \quad \mathrm{NO}_{3}-\mathrm{N}$ and $\mathrm{NO}_{2}-\mathrm{-N}$ concentrations and the index scores (Fig. 2), indicating that they make a remarkable contribution to $\mathrm{WQI}_{\mathrm{min}}$. Even though an interference of point or nonpoint sewage and domestic discharges may not be ruled out, $\mathrm{WQI}_{\text {min }}$ provided a more precise approach than $\mathrm{WQI}_{\mathrm{obj}}$ and $\mathrm{WQI}_{\min }$ in assessing the effects of effluents on the water quality in the lake. The better performance could be because TDS and TSS are the dominant fractions of TS (Fig. 3), in catchments under the effect of diffuse discharges from industrial as well as treated and untreated sewage wastes of urban community (Neal and Jarvie, 2005; Jarvie et al., 2008). For a well thrive aquaculture, DO and BOD are critical to a certain degree (Sindilariu, 2007; Shamir et al., 2015), are dominated by COD as well as A/T and W/T, (Fig. 4 and 5) respectively (Foy and Rosell, 1991; Roque d'Orbcastel et al., 2008; Mehet and Huseyin, 2014). Chloride can be 
removed up to $90-95 \%$ via aeration and distillation, but the removal of hardness is highly difficult (Sindilariu, 2007; Sindilariu et al., 2009b); thereby the ratio of alkalinity may increase (Dalsgaard and Pedersen, 2011).

The results suggest that a Powai lake $\mathrm{WQI}_{\mathrm{obj}}$ would be a useful approach for assessment of impacts on the receiving run-off, and $\mathrm{NH}_{4}+-\mathrm{N}$ and $\mathrm{NH}_{2}+-\mathrm{N}$ seem to be better indicators for aquacultural impacts as opposed to the suggestion of Simoes et al., (2008), who noted that eutrophication could be the typical indicator.

Therefore, as a next step in the parameter selection we calculated $\mathrm{WQI}_{\text {min }}$ based on transparency and turbidity. $\mathrm{WQI}_{\text {min }}$ produced highly similar scores for all sampling months, significant difference between these two affected productivity of the lake. However, $\mathrm{WQI}_{\text {min }}$ clearly separated the sampling months with respect to their water quality status, and rated monsoon and post-monsoon as "good" and "medium" classes, respectively for all conditions and annual period, which also revealed by Fabiano et al., (2008). An attempt at the index calculation $\left(\mathrm{WQI}_{\mathrm{NH}} 4\right.$, $\mathrm{WQI}_{\text {cond }}$ ) using only a single parameter $\left(\mathrm{NH}_{4}+-\mathrm{N}\right.$ or conductivity), which is actually an environmental quality standard (EQS), resulted in higher water quality classes of the sampling stations than $\mathrm{WQI}_{\text {min. }}$ Moreover, $\mathrm{WQI}_{\mathrm{NH} 4}$ appeared to have a higher relation with $\mathrm{WQI}_{\min }$ than $\mathrm{WQI}_{\text {cond }}$. Although $\mathrm{WQI}_{\mathrm{NH}^{4}}$ had a good association with $\mathrm{WQI}_{\min }$ premonsoon, there was not a reasonable relation for all the sampling months when compared with monsoon.

This may suggest that the EQS of $\mathrm{NH}_{4}+-\mathrm{N}$ alone seemed to have been a good indicator for assessment of aquacultural impacts in Powai lake, but it was still insufficient for assessment of the entire water body probably due to interference of several other factors such as nitrification, dilution, diffuse loads from domestic waste activities, eutrophication, etc.

This study clearly reveals CCME WQI indicates that water quality in the Powai lake can be classified as 'Marginal' between November 2016 and October 2017. Water quality is frequently threatened or impaired; conditions often depart from natural/normal or desirable levels. Measured A/T, W/T, trans, turbidity, DO, chloride, $\mathrm{TP}, \mathrm{NO}_{2}+-\mathrm{N}$, $\mathrm{COD}$, conductivity and $\mathrm{Co}_{2}$ concentrations exceeded objectives on one, nine, two, ten, two, two, nine, one, six, one and three occasions respectively; however, these excursions were fairly small and likely reflect natural events. $\mathrm{WQI}_{\mathrm{obj}}$ calculation based on too many variables fails to differentiate the affected months from the discharges of waste. $\mathrm{WQI}_{\min }$ calculation using few parameters will be a cost, time and effort-saving way that are a fundamental aspect of effective water quality monitoring. The index presents a more accurate way to evaluate the presence of aquatic activities. The quality values showed a critical situation for some stations that could be used to support of managerial actions. $\mathrm{WQI}_{\min }$ can be used in the evaluation of diffuse and point source control performances. This way $\mathrm{WQI}_{\min }$ may be used as a new tool for assessment of water quality and can be employed in the aquatic body monitoring. This tool is important because it decreases the cost of monitoring programs and the expenses associated with the implantation for aquaculture.

\section{Acknowledgment}

This study was sponsored and supported by Government of India through ICARInternational Fellowship and ICAR-CIFE (Deemed University) Mumbai, for the necessary facilities for data collection and analysis to conduct the research. 


\section{References}

Akkoyunlu, A., and Akıner, M.E. (2012). Pollution evaluation in streams using water quality indices: a case study from Turkey's Sapanca Lake Basin. Ecol. Indic. 18, 501-511.

APHA, AWWA, WEF, (1998). Standard Methods for the Examination of Water and Wastewater, 20th ed. American Public Health Association, Washington, DC. 930-931

Bakan, G., Ozkoc s, H. B., Tulek, S., and Cuce, H., (2010). Integrated environmental quality assessment of Kizılırmak river and its coastal environment. Turkish J. Fish Aquat. Sci. 10, 453-462.

Bergheim, A., and Brinker, A. (2003). Effluent treatment for flow-through systems and European Environmental Regulations. Aquac. Eng. 27, 61-77.

Boyacioglu, H. (2010). Utilization of the water quality index method as a classification tool. Environ. Monit. Assess. 167, 115-124.

Boyacioglu, H., and Boyacioglu, H. (2007). Surface water quality assessment by environ-metric methods. Environ. Monit. Assess. 131, 371-376.

Carpenter, S.R., Caraco, N.F., Correll, D.L., Howarth, R.W., Sharpley, A.N., and Smith, V.H. (1998). Nonpoint pollution of surface waters with phosphorous and nitrogen. Ecol. Appl. 8, 559-568.

CCME, (2001). Canadian Water Quality Guidelines for the Protection of Aquatic Life: Canadian Water Quality Index 1.0 Technical Report. Canadian Environmental Quality Guidelines, Winnipeg. 5

Dalsgaard, A.J.T., and Pedersen, P.B. (2011). Solid and suspended/dissolved waste $(\mathrm{N}, \quad \mathrm{P}, \mathrm{O})$ from rainbow trout (Oncorynchus mykiss). Aquaculture 313, 92-99.
Debels, P., Figueroa, R., Urrutia, R., Barra, R. and Niell, X. (2005). Evaluation of water quality in the Chillan River (Central Chile) using physicochemical parameters and a modified water quality index. Environ. Monit. Assess. 110, 301-322.

Fabiano D. S. S., Altair B. M., Marcia C. B., Sonia M. N. G. and Maria J. S. Y. (2008). Water quality index as a simple indicator for aquaculture effects on aquatic bodies. Ecological Indicators 8, 476-484.

FAO, (2010). The State of World Fisheries and Aquaculture 2010. Food and Agriculture Organization of the United Nations, Fisheries and Aquaculture Department, Rome. 62

FAO, (2016). The State of World Fisheries and Aquaculture 2016. Food and Agriculture Organization of the United Nations, Fisheries and Aquaculture Department, Rome. 204

Ferreira, N.C., Bonetti, C. and Seiffert, W.Q. (2011). Hydrological and Water Quality Indices as management tools in marine shrimp culture. Aquaculture 318, 425433.

Folke, C., and Kautsky, N. (1992). Aquaculture with its environment: prospects for sustainability. Ocean Coast Manag. 17, 5-24.

Foy, R.H. and Rosell, R., 1991. Fractionation of phosphorus and nitrogen loadings from a Northern Ireland fish farm. Aquaculture, 96, 31-42.

Hall, P.O.J., Holby, O., Kollberg, S., and Samuelsson, M.O. (1992). Chemical fluxes and mass balances in a marine fish cage farm. IV. Nitrogen. Mar. Ecol. Prog. Ser. 89, 81-91.

Holby, O. and Hall, P.O.J. (1991). Chemical fluxes and mass balances in a marine fish cage farm. II. Phosphorus. Mar. Ecol. Prog. Ser. 70, 263-272. 
Jarvie, H.P., Withers, P.J.A., Hodgkinson, R., Bates, A., Neal, M., Wickham, H.D., Har- man, S.A. and Armstrong, L. (2008). Influence of rural land use on stream water nutrients and their ecological significance. J. Hydrol. 350, 166-186.

Kannel, P.R., Lee, S., Lee, Y.-S., Kanel, S.R. and Khan, S.P. (2007). Application of Water Quality Indices and dissolved oxygen as indicators for river water classification and urban impact assessment. Environ. Monit. Assess. 132, 93-110.

Koc,er, M.A.T., Kanyılmaz, M., Yılayaz, A. and Sevgili, H. (2013). Waste loading into a regulated stream from land-based trout farms. Aquacult. Environ. Interact. 3, 187-195.

Kohil, M. P. S., K. Dube, C. Prakash, C.S. Chaturvedi and R. J. Jadhav (1998). Observations on some hydrobiological features of lake Powai near Mumbai (Maharastra). Journal of Inland Fisheries Society, India. 30: 37-49

Lermontov, A., Yokoyama, L., Lermontov, M. and Machado, M.A.S. (2011). A fuzzy water quality index for watershed quality analysis and management. In: Broniewicz, E. (Ed.), Environmental Management in Practice. InTech, Crotia, pp. 387-410.

Leung, K.M.Y., Chu, J.C.W., and Wu, R.S.S. (1999). Nitrogen budgets for the areolated grouper, Epinephelus areolatus, cultured under laboratory conditions and in open-sea cages. Mar. Ecol.-Prog. Ser. 186, 271-281.

Manahan, S.E. (2000). Environmental Chemistry, 7th ed. Lewis Publishers, Boca Raton. 876

Mander, U., Kull, A. and Kuusemets, V. (2000). Nutrient flows and land use change in a rural catchment: a modelling approach. Landsc. Ecol. 15, 187-199.
Martin K., and Madelene O. (2016). Remote sensing of vegetation in the SudanoSahelian zone: A literature review from 1975 to 2014. Journal of Arid Environments 124, 257-269.

Massoud, M.A. (2010). Assessment of water quality along a recreational section of the Damour River in Lebanon using the water quality index. Environ. Monit. Assess. 184, 4151-4160.

Mehmet A. T. K. and Huseyin S. (2014). Parameters selection for water quality index in the assessment of the environmental impacts of land-based trout farms. Ecological Indicators 36, 672-681.

Moss, B. (2008). Water pollution by agriculture. Philos. T. R. Soc. B 363, 659-666.

Neal, C. and Jarvie, H.P. (2005). Agriculture, community, river eutrophication and the Water Framework Directive. Hydrol. Process. 19, 1895-1901.

O'Bryen, P.J. and Lee, C.S. (2003). Management of aquaculture effluents workshop discussion summary. Aquaculture 226, 227-242.

Pesce, S.F. and Wunderlin, D.A. (2000). Use of water quality indices to verify the impact of Cordoba city (Argentina) on Suquya River. Water Res. 34, 29152926.

Roque d'Orbcastel, E., Blancheton, J.P., Boujard, T., Aubin, J., Moutounet, Y., Przybyla, C. and Belaud, A. (2008). Comparison of two methods for evaluating waste of a flow through trout farm. Aquaculture 274, 72-79.

Rosemond, S., Duro, D.C. and Dube, M. (2009). Comparative analysis of regional water quality in Canada using the Water Quality Index. Environ. Monit. Assess. 156, 223-240.

Said, A., Stevens, D.K. and Sehlke, G. (2004). An innovative index for 
evaluating water quality in streams. Environ. Manag. 34, 406-414.

Shamir, E., Megdal, S. B., Carrillo, C., Castro, C. L., Chang, H. I., Chief, K., Corkhill, F. E., Eden, S., Georgakakos, K. P., Nelson K. M., and Prietto, J. (2015). Climate change and water resources Management in the upper Santa Cruz river, Arizona. Journal of Hydrology 521, 18-33. hppt://dx.doi.org/10.1016/j.jhdrol.2014

Simoes, F.D., Moreira, A.B., Bisinoti, M.C., Gimenez, S.M.N. and Yabe, M.J.S. (2008). Water quality index as a simple indicator of aquaculture effects on aquatic bodies. Ecol. Indic. 8, 476-484.

Sindilariu, P.D. (2007). Reduction in effluent nutrient loads from flow-through facilities for trout production: a review. Aquac. Res. 38, 1005-1036.

Sindilariu, P.D., Brinker, A. and Reiter, R. (2009b). Waste and particle management in a commercial, partially recirculating trout farm. Aquac. Eng. 41, 127-135.

Sindilariu, P.D., Reiter, R. and Wedekind, H. (2009a). Impact of trout aquaculture on water quality and farm effluent treatment options. Aquat. Living Resour. 22, 93-103.

Tacon, A.G.J. and Forster, I.P. (2003). Aquafeeds and the environment: policy implications. Aquaculture 226, 181189.

Wu, R.S.S. (1995). The environmental impact of marine fish culture: towards a sustainable future. Mar. Pollut. Bull. 31, 159-166.

Wu, R.S.S., Lam, K.S., Mackay, D.W., Lau, T.C., and Yam, V. (1994). Impact of marine fish farming on water quality and bottom sediment, a case study in the sub-tropical environment. Mar. Environ. Res. 38, 115-145.

Zhang, M. and Zhang, M. (2007). Assessing the impact of leather industries on the quality of water discharged into the East China Sea from Wenzhou Watersheds. J. Environ. Manage. 85, 393-403.

Zhu, C., Chen, Y., Li, W., and Ma, X. (2014). Effect of herbivory on the growth and photosynthesis of replanted Calligonum caput-medusae saplings in an infertile arid desert. Plant Ecology 215, 155167.

\section{How to cite this article:}

Usman, A., K. Dube, S.P. Shukla, P. Salaskar, C. Prakash, P.B. Sawant and Singh, R. 2018. Water Quality Index as a Tool for Assessment of Status of an Urban Lake of Mumbai. Int.J.Curr.Microbiol.App.Sci. 7(04): 520-533. doi: https://doi.org/10.20546/ijcmas.2018.704.061 